\title{
Editorial Preface to the special issue
}

Hong Kong Public Administration Association (HKPAA) was established in 1990 to promote and enhance the quality of research and practice of public sector management in Hong Kong and the region. It provides forums for discussions of important issues in public policies and management through regular dinner talks, seminars and conferences by renowned leaders in both public and private organizations.

Starting in 2020, four renowned international scholars and officials from the region have been invited to serve as the Association's Honorary Advisors to provide advice to guide its development in the third decade of the twenty-first century. They are Professor Jiang Wu of the Chinese Academy of Personnel Science, Ministry of Human Resources and Social Security of China; Professor Siu-kai Lau of The Chinese University of Hong Kong in the Hong Kong SAR; Professor Jon Quah, an Anti-Corruption Consultant from Singapore; and Professor Pan-suk Kim of Yonsei University from South Korea.

A new website for the Association has been launched in 2020 to mark the $30^{\text {th }}$ Anniversary of HKPAA. It features new icons on speeches of top leaders given at our luncheons, dinners and conferences, full PDF versions of all issues of the PAP journal as well as photo albums of all our activities.

Since 2018, PAP has been published online in open access on the Emerald Insight Platform. In order to have the journal indexed in ESCI and SCOPUS as soon as possible, PAP now publishes three issues with at least one special issue per year. To maintain a high academic standard, a new Asia-Pacific Editorial Board has been set up with top academics from the region. In addition, an International Editorial Advisory Board consisting of renowned scholars from leading universities in the United States, Canada, United Kingdom, Switzerland, and Australia has also been formed.

In this special issue on "Public Governance, Integrity, Performance and Inclusiveness in Asia”, we are grateful to have Professor Ahmed Shafiqul Huque from McMaster University, Canada and Professor Habib Zafarullah from University of New England, Australia as guest editors. With their academic expertise and wide networking, seven papers on Hong Kong, Thailand, Nepal, United Arab Emirates, Sri Lanka as well as other Asian and African countries written by scholars and practitioners from Canada, Thailand, Nepal, Australia, Norway, Bangladesh, Brunei, United Arab Emirates, Sri Lanka, and Ghana are included in this special issue. We hope these papers will make significant contributions to the understanding of various issues on public sector governance in Asia.

\author{
Peter K.W. Fong \\ Editor-in-Chief, PAP Journal \\ President, Hong Kong Public Administration Association
}

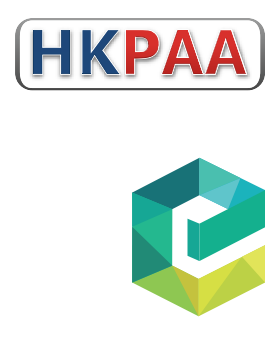

(C) Peter K.W. Fong. Published in Public Administration and Policy. Published by Emerald Publishing Limited. This article is published under the Creative Commons Attribution (CC BY 4.0) license. Anyone may reproduce, distribute, translate and create derivative works of this article (for both commercial and non-commercial purposes), subject to full attribution to the original publication and authors. The full terms of this license may be seen at http://creativecommons.org/licences/by/4.0/legalcode

Public Administration and Policy Vol. 23 No. 2,2020 pp. $107-108$
Emerald Publishing Limited DOI 10.1108/PAP-09-2020-041 
About the Editor-in-Chief

23,2

Professor Peter K.W. Fong, PhD (New York University), is President of Hong Kong Public Administration Association and Editor-in-Chief of PAP Journal; and Managing Director of Peter Fong \& Associates Ltd. He teaches Strategic Management and supervises DBA students' dissertations of the University of Wales and teaches Public Policy at The Chinese University of Hong Kong. He also holds advisory and visiting Professorships in several Mainland China universities, namely Tsinghua, Renmin, Tongji, and Tianjin Universities. He is a member of Hong Kong Institute of Planners, Planning Institute Australia, and Chartered Institute of Logistic and Transport. He was formerly a Teaching Fellow, Judge Business School, University of Cambridge; Director of EMBA programme, HKU Business School; Associate Professor, Department of Urban Planning \& Urban Design, HKU; Executive Vice President \& Professor, City University of Macao (formerly AIOU); Head, Centre for Executive Development, HKU SPACE; Honorary Professor, China Training Centre for Senior Civil Servants of Ministry of Human Resource \& Social Security, PRC; Studies Director, Civil Service Training \& Development Institute of the HKSAR Government; Visiting Scholar, MIT; and Consultants, the World Bank and Delta Asia Bank in Macao. Peter K.W. Fong can be contacted at: fongpeter@netvigator.com 